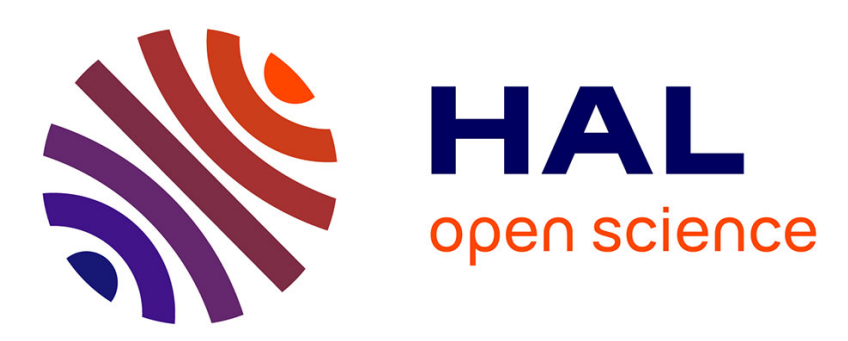

\title{
Interface Tailoring in Carbon Fibres Reinforced Metal Matrix Composites
}

\author{
J. Bouix, M. Berthet, F. Bosselet, R. Favre, M. Peronnet, J. Viala, C. \\ Vincent, H. Vincent
}

\section{- To cite this version:}

J. Bouix, M. Berthet, F. Bosselet, R. Favre, M. Peronnet, et al.. Interface Tailoring in Carbon Fibres Reinforced Metal Matrix Composites. Journal de Physique IV Proceedings, 1997, 07 (C6), pp.C6191-C6-205. 10.1051/jp4:1997616 . jpa-00255715

\section{HAL Id: jpa-00255715 https://hal.science/jpa-00255715}

Submitted on 1 Jan 1997

HAL is a multi-disciplinary open access archive for the deposit and dissemination of scientific research documents, whether they are published or not. The documents may come from teaching and research institutions in France or abroad, or from public or private research centers.
L'archive ouverte pluridisciplinaire HAL, est destinée au dépôt et à la diffusion de documents scientifiques de niveau recherche, publiés ou non, émanant des établissements d'enseignement et de recherche français ou étrangers, des laboratoires publics ou privés. 


\title{
Interface Tailoring in Carbon Fibres Reinforced Metal Matrix Composites
}

\author{
J. Bouix, M.P. Berthet, F. Bosselet, R. Favre, M. Peronnet, J.C. Viala, C. Vincent and H. Vincent \\ Laboratoire des Multimatériaux et Interfaces (LMI), UMR 5615 du CNRS, Université Claude Bernard \\ Lyon I, 43 boulevard du 11 novembre 1918, 69622 Villeurbanne, France
}

\begin{abstract}
The fabrication of high performance metal matrix composites requires the optimization of the interfacial bonding, which supposes a strict control of the reactivity and of the wettability between the matrix and the reinforcement, specially for materials produced by casting techniques. In this scope, two methods are described consisting on the one hand, in the surface treatment of carbon fibres by a particular type of CVD and, on the other hand, in modifying the composition of the matrix. The two methods can be used either separately or in combination, sucessful tailoring of the interface being the result of thermodynamic or kinetic effects.
\end{abstract}

\section{INTRODUETION}

The mechanical behaviour of inorganic composites (metallic and ceramic matrix) depends obviously on the characteristics of the reinforcement, consisting for instance of fibres and on these of the matrix, but also mainly on the nature of the interfacial bonding between the fibre and the matrix $[1,2]$.

This bonding must be strong enough to provide a good load transfer from the matrix to the fibres, but weak enough to trap the cracks by diverting them along the interface and to prevent their propagation through the fibre with a brittle rupture of the composite.

In the case of metallic matrix composites reinforced by ceramic fibres, the strength of the interfacial bonding is generally connected with the chemical interaction between the matrix and the fibre during the processing of the material. Relating to this problem, carbon fibres are very performant because of their lightness and high mechanical characteristics, which can be modified by changing the nature of the precursor and the conditions of their elaboration. For instance, those obtained by pyrolysis of a polyacrylonitrile yarn (T300 type) generally little graphitized, have a high tensile strength but are very reactive particularly with metals like aluminium, giving a carbide, or with oxygen, losing weight above $400^{\circ} \mathrm{C}$ in air. On the contrary, those obtained from a pitch are more graphitized, less reactive and have a higher modulus.

During the fabrication of an aluminium matrix composite reinforced by carbon fibres, it is difficult to prevent the formation of aluminium carbide, which weakens the fibre and causes the composite to become highly sensitive to corrosion by humid air.

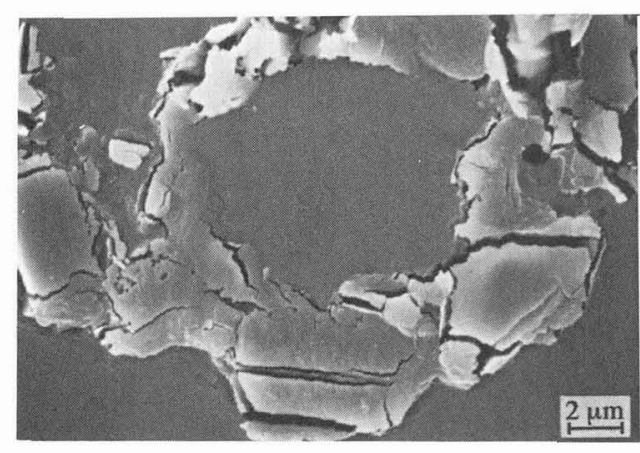

a)

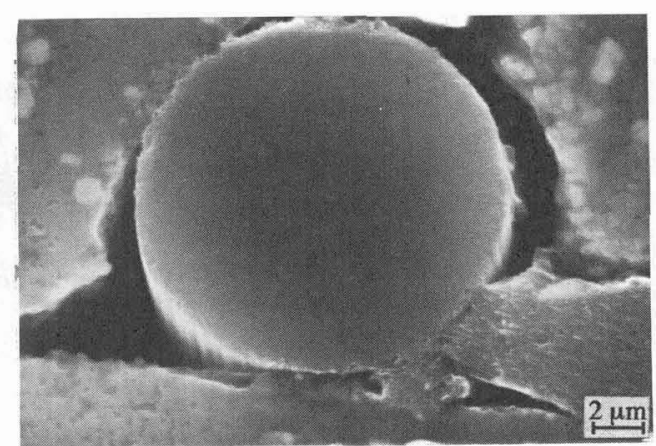

b)

Figure 1: P 55 carbon filament after treatment, during $15 \mathrm{~min}$ at $680^{\circ} \mathrm{C}$ in pure aluminium, showing a strong interaction giving aluminium carbide (a), during 5 hours at $730^{\circ} \mathrm{C}$ in pure magnesium without reaction or wetting (b). 
As shown in figure 1a, this carbide has no protective effect on the fibre and it is then necessary to reduce as much as possible its formation. On the contrary, neither reactivity nor wettability occur between the same fibre and molten magnesium and the impregnation is very bad as shown in figure $1 \mathrm{~b}$. In the latter case, it is necessary to create a controlled reactivity for obtaining a satisfactory composite.

As far as we are concerned, we have developed two complementary approaches in view of optimizing this chemical interaction between the matrix and the reinforcement. The first, specially adapted to carbon fibres, consists in coating each filament (typically a few thousands) by a thin carbide layer protecting it against oxygen or metals. Such a result is obtained by using Reactive Chemical Vapor Deposition (RCVD), in which the coating growth is self-regulated by the diffusion of carbon through the as-formed layer. The second lies in incorporating into the matrix an addition element decreasing its chemical reactivity with the fibre coatings or, conversely, promoting a controlled reaction at the matrix/fibre interface.

\section{CERAMIC COATINGS ON CARBON FIBRES BY RCVD}

Over recent years, a great deal of work has been done in the area of providing a thin coating of ceramics on carbon fibres to solve the problems of interfacial compatibilities in aluminium composites. An encountered problem arises from the difficulty in coating each filament of a tow, in particular, the deposit on the tow periphery must be avoided, and there are few methods which are satisfactory. Among these methods, reactive CVD or RCVD is interesting because the treatment takes place at normal pressure and the coating duration is lower than $1 \mathrm{~min}$. In the RCVD process, the fibre is heated in a gaseous mixture which reacts with the carbon fibre, resulting in a conversion coating of carbide. This method is different from classical CVD because the gas phase brings only one of the two elements constituting the carbide, the carbon being brought by the fibre itself. The carbide coating is not grown on the fibre, but it results from the chemical transformation of a superficial layer of this substrate, which gives a very good bonding and adherence. The chemical reaction between the carbon of the fibre and a gas precursor provides a self regulation of the coating thickness, because the coating growth requires the diffusion of carbon through the formed carbide layer. In our laboratory, single layers of $\mathrm{SiC}$, TiC or $\mathrm{B}_{4} \mathrm{C}$, mixed layers of $\mathrm{TiC}-\mathrm{SiC}$ or $\mathrm{SiC}-\mathrm{B}_{4} \mathrm{C}$ and double layers of $\mathrm{SiC} / \mathrm{B}_{4} \mathrm{C}$ or $\mathrm{B}_{4} \mathrm{C} / \mathrm{TiB}_{2}$ have been applied to different carbon fibres using RCVD method. Double layer coatings have been performed by a succession of two RCVD: formation of a carbide layer and convertion of a part of this carbide into a new ceramic (carbide, boride). The successful reinforcement of a composite with carbide coated fibres will require a coating of sufficient thickness to afford protection to the fibres but thin enough to limit the strength decrease of the fibre. Therefore, it is important to optimize the RCVD conditions and to deposit a $C_{\text {pyro }}$ film on the raw fibers before the RCVD process. The effect of the various coatings on the tensile strength of the as-coated fibres and on the protection against aluminium and air were investigated.

\subsection{Experimental techniques}

A pilot plant in our laboratory permits the continuous coating of fibres with a total length of up to several hundred meters (Figure 2). The reactor consists of a horizontal silica tube (22 $\mathrm{mm}$ inner diameter) closed at either end by a stainless steel flange.

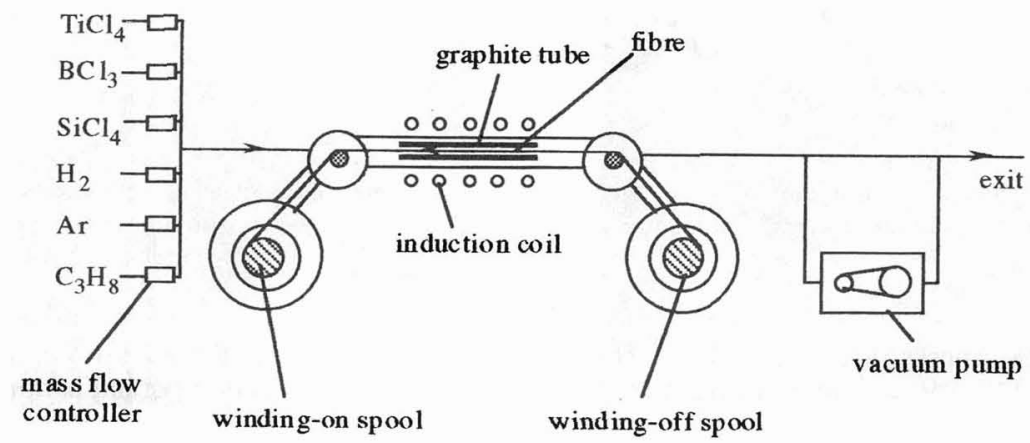

Figure 2: Schematic diagram of the coating apparatus 
The flanges contain stainless steel spools; the spools permit the fibres to be transported through the reactor at a rate varying from 1 to $50 \mathrm{~m} . \mathrm{h}^{-1}$. The fibre is heated in an induction furnace; the temperature of the susceptor is measured by an optical pyrometer and it is taken as the deposition temperature. $\mathrm{TiCl}_{4}$ is saturated in hydrogen and $\mathrm{SiCl}_{4}$ vapour is carried in the reactor by hydrogen or by argon. The flow rates of $\mathrm{H}_{2}, \mathrm{BCl}_{3}, \mathrm{C}_{3} \mathrm{H}_{8}$ and $\mathrm{Ar}$ are monitored by gas mass flow meters. The $\mathrm{RCVD}$ experiments are performed under atmospheric pressure. A vacuum pump permits to evacuate the reactor before the coating process and to realized $\mathrm{C}_{\text {pyro }}$ films from $\mathrm{C}_{3} \mathrm{H}_{8}$ under low pressure in the same apparatus.

Three kinds of carbon fibres were used in this study : two high strength fibres (T300-99 and M40B from Torayca) and one high modulus fibre (FT500 from Tonen). T300-99 fibres are commercialized without surface treatment or sizing treatment. Prior to use, surfaces of M40B and FT500 fibres were cleaned of any organic substances by passing them through a furnace containing an argon atmosphere at $1000^{\circ} \mathrm{C}$. After deposition, the samples were characterized using various techniques such as XRD, XPS, SEM, Raman, TEM and EPMA. Strength measurements performed on single filaments $(20 \mathrm{~mm})$ complete the characterization (crosshead speed : $0.1 \mathrm{~mm} \cdot \mathrm{min}^{-1}$ ).

\subsection{Thermodynamic approach}

In order to improve the understanding of the RCVD process and the knowledge of its behaviour with respect to variations in temperature or concentrations of the various precursors, a chemical equilibrium thermodynamic analysis of the gas reactants-substrates system is required. In a RCVD system, the carbon substrate participates in the reaction, and its surface is covered by a layer of a new solid phase which isolates the carbon from the gaseous mixture. The carbide layer can grow as a result of carbon diffusion through the layer. The carbide formed on the substrate depends on the availability and the concentration of carbon at the reaction interface. Thermodynamic predictions remain possible on the basis of a heterogeneous system in which the parameters are the temperature, the initial composition of the gas phase and the amount of carbon. RCVD phase diagrams have been established in other publications [3-8]. The RCVD diagrams predict condensed phases in equilibrium under the given conditions of interest. Figure 3 is an example of a predominance diagram at $1300 \mathrm{~K}$. The initial system is defined by the number of moles of each species $\left(\mathrm{n}^{\circ} \mathrm{i}\right)$. It evidences 4 domains : TiC $0.95+\mathrm{C}, \mathrm{TiC}_{\mathrm{y}}(0.54<\mathrm{y}<0.95), \mathrm{TiC}_{0.54}+\mathrm{Ti}$ and $\mathrm{G}$ (gaseous domain). This diagram shows that the chemical composition of a titanium carbide coating would not be constant during a RCVD experiment. Nevertheless, the use of a $\mathrm{TiCl}_{4}$ partial pressure higher than $10^{-2} \mathrm{~atm}$ permits to reduce the $C$ gradient in the coating, and in the case of thin layer $(<0,1 \mu \mathrm{m})$ on carbon fibres, the $\mathrm{C}$ diffusion through the layer is quick, and it is supposed that the carbide composition is near $\mathrm{TiC}_{0.9}$.

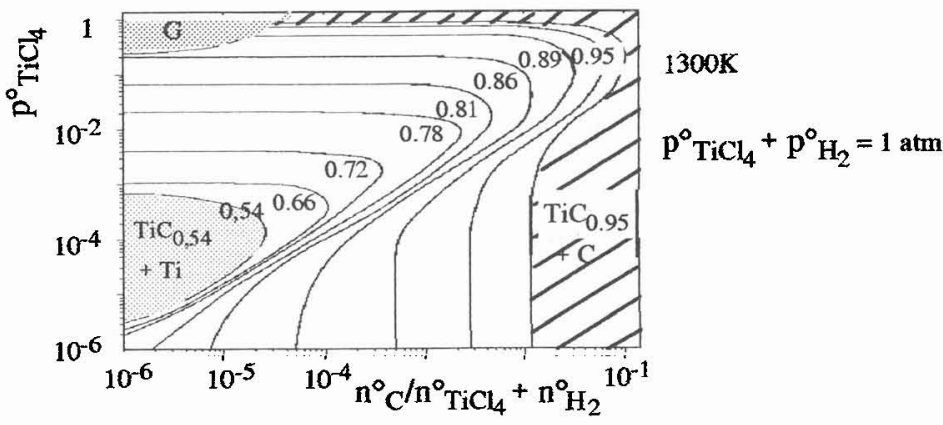

Figure 3: RCVD phase diagram in the $\mathrm{TiCl}_{4}-\mathrm{H}_{2}-\mathrm{C}(\mathrm{gr})$ system. The different lines indicate the composition y of the $\mathrm{TiC}$ phase at equilibrium under given conditions. It is noted that $\mathrm{y}$ increases with the initial pressure of $\mathrm{TiCl}_{4}$ $\left(\mathrm{p}^{\circ} \mathrm{TiCl}_{4}\right)$.

During a RCVD process, a gas mixture of constant composition sweeps the reactor continuously. The product gases are then forced out of the reactor. In other words, the time is an important parameter since the amount of gaseous reactants can vary from zero to infinity between the beginning and the end of the treatment and thus, transient solid phases may be formed. It is possible to use a predictive model on the basis that the RCVD process can be considered as a sequence of successive steps of same duration, at constant temperature. 

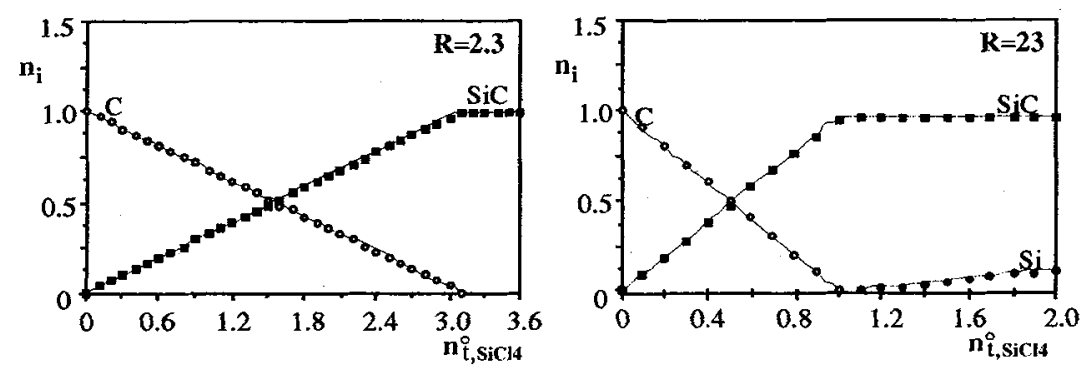
(a) : SiC coating on carbon fibre

System $\mathrm{SiCl}_{4}-\mathrm{H}_{2}-\mathrm{C}_{(\mathrm{gr})}$ at $\mathrm{T}=1500 \mathrm{~K}$

$\mathrm{n}_{\mathrm{C}}=1$ mole step : $n^{\circ} \mathrm{SiCl}_{4}=0.1$ mole
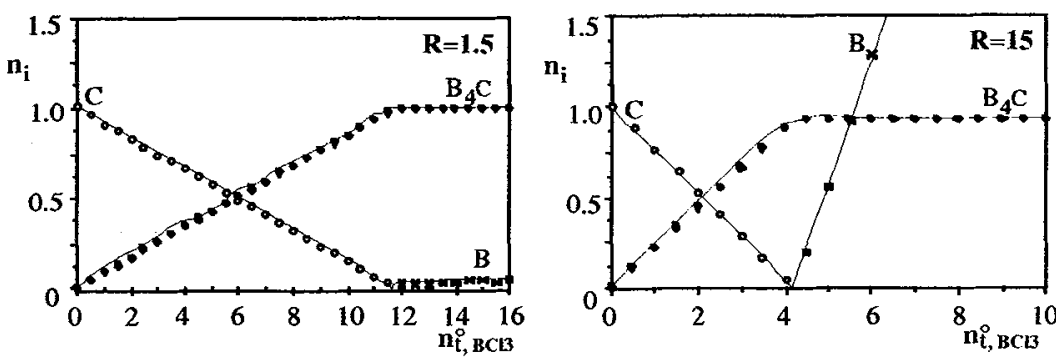

(b) : $\mathrm{B}_{4} \mathrm{C}$ coating on carbon fibre

System $\mathrm{BCl}_{3}-\mathrm{H}_{2}-\mathrm{C}_{(\mathrm{gr})}$

at $\mathrm{T}=1600 \mathrm{~K}$

$\mathrm{n}^{\circ} \mathrm{C}=1$ mole

step : $\mathrm{n}^{\circ}{ }_{\mathrm{BCl}_{3}}=0.5$ mole
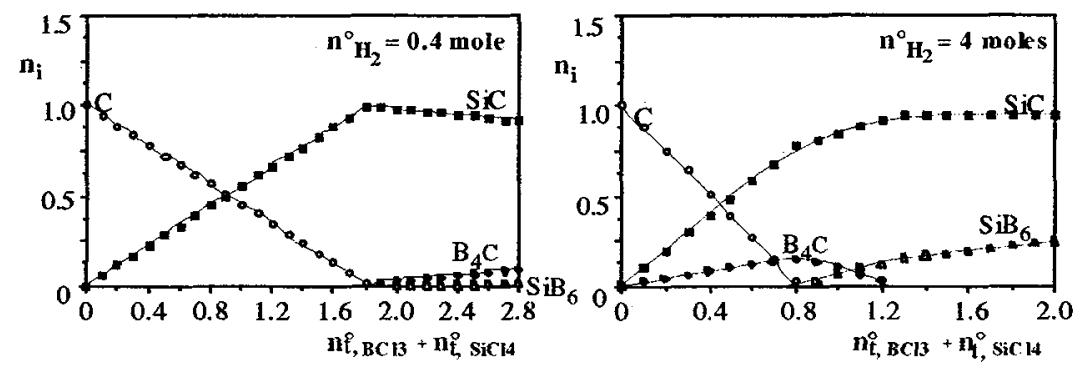

(c) : $\mathrm{B}_{4} \mathrm{C}-\mathrm{SiC}$ mixed coating on carbon fibre

System $\mathrm{BCl}_{3}-\mathrm{SiCl}_{4}-\mathrm{H}_{2}-\mathrm{C}_{(\mathrm{gr})}$ at $\mathrm{T}=1500 \mathrm{~K}$

$\mathrm{n}_{\mathrm{C}}=1$ mole

step : $\mathrm{n}^{\circ} \mathrm{SiCl}_{4}=0.1$ mole + $\mathrm{n}^{\circ}{ }_{\mathrm{BC}_{3}}=0.1$ mole
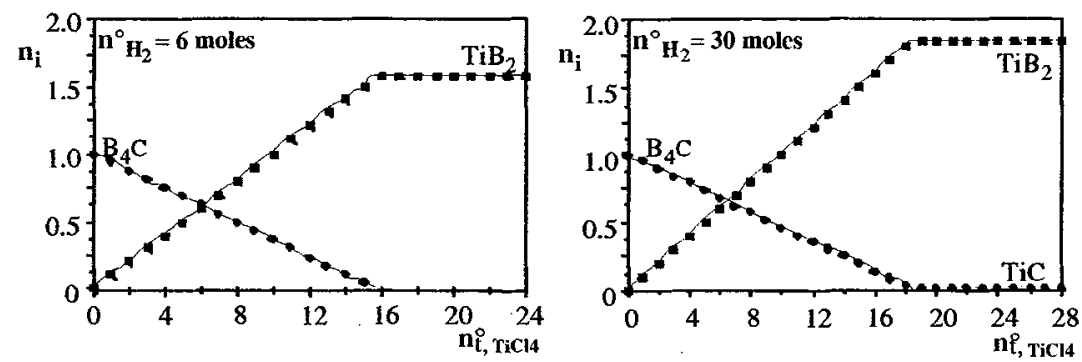

(d) : $\mathrm{TiB}_{2}$ coating on $\mathrm{B}_{4} \mathrm{C}$ coated carbon fibre

System $\mathrm{B}_{4} \mathrm{C}-\mathrm{TiCl}_{4}-\mathrm{H}_{2}$ at $\mathrm{T}=1000 \mathrm{~K}$

$\mathrm{n}^{\circ} \mathrm{B}_{4} \mathrm{C}=1$ mole

step : $\mathbf{n}^{\circ}{ }^{\circ}$ iCl $_{4}=0.1$ mole

Figure 4: Thermodynamic analysis for the various studied systems $\left(R=n^{\circ} \mathrm{H}_{2} / \mathrm{n}^{\circ}\right.$ chloride $)$

For the thermodynamic study of a coating, the method consists in calculating equilibrium compositions for different heterogeneous solid-gas systems: the first system is defined by an excess of the solid phase $\left(\mathrm{n}^{\circ} \mathrm{C}=\right.$ 1 mole, or $n^{\circ}{ }_{B 4} \mathrm{C}=1$ mole) and by a small quantity of gaseous reactants $\left(n^{\circ}\right.$ chloride, $n^{\circ}{ }_{2}$ ), each following system consists of the same values $n^{\circ}$ chloride and $n^{\circ} \mathrm{H}_{2}$ and the amount of solid phases found in the precedent calculation. This model supposes that equilibrium is reached quickly; it enables the prediction of the chemical nature of the deposited phases as a function of reaction conditions, e.g. the total quantity of chloride ( $\mathrm{n}^{\circ}$,chloride) introduced in the reactor, and states more precisely the effects of treatment time on the chemical composition of the coating. It has been very useful for the choice of the input gas composition allowing the coating of a carbon fibre by a carbide, a mixture of carbides or a boride. 
The curves a-d in figure 4 illustrate this approach for four cases, they give the variations of the mole numbers of solid species as a function of mole number of chloride $\left(n^{\circ}\right.$,chloride) with all other parameters held constant at an arbitrary set of standard conditions (pressure $=1 \mathrm{~atm}$, temperature, composition of the initial gaseous phase). For each case, two curves are given to evidence the influence of the $R$ ratio between $\mathrm{n}^{\circ} \mathrm{H} 2$ and $\mathrm{n}^{\circ}$ chloride-

From this thermodynamic approach, the RCVD conditions can be deduced:

- In the $\mathrm{SiCl}_{4}-\mathrm{H}_{2}-\mathrm{C}$ system, the two curves show that pure $\mathrm{SiC}$ or $\mathrm{Si}-\mathrm{SiC}$ mixture can be deposited (figure $4 a)$. A low dilution ratio $R$ inhibits the silicon deposition.

- The formation of $\mathrm{B}_{4} \mathrm{C}$ requires the $\mathrm{H}_{2}$ presence in the input gas phase. The calculations predict always codeposition of $\mathrm{B}_{4} \mathrm{C}$ and $\mathrm{B}$ (figure $4 \mathrm{~b}$ ). Nevertheless, $\mathrm{B}$ deposit amount will be limited by using an input $\mathrm{BCl}_{3}$-rich mixture.

- In the case of a $\mathrm{C}$ substrate heated in $\mathrm{a} \mathrm{SiCl}_{4}-\mathrm{BCl}_{3}$ mixture, the thermodynamics foresees the formation of $\mathrm{SiC}, \mathrm{B}_{4} \mathrm{C}$ and $\mathrm{SiB}_{6}$ (figure $4 \mathrm{c}$ ). The boron silicide amount increases with $\mathrm{H}_{2}$ partial pressure. The curve drawn for $\mathrm{R}=4$ shows that $\mathrm{SiC}-\mathrm{B}_{4} \mathrm{C}$ codeposition is possible without $\mathrm{SiB}_{6}$ and that the ratio $\mathrm{n}_{\mathrm{SiC}} / \mathrm{n}_{\mathrm{B}} \mathrm{C}$ evolves with the step number. Thus mixed deposits of different compositions can be obtained in a RCVD process.

- $\mathrm{B}_{4} \mathrm{C}$ conversion into $\mathrm{TiB}_{2}$ is thermodynamically possible (figure $4 \mathrm{~d}$ ). Conversion is improved when increasing $\mathrm{H}_{2}$ partial pressure; however with a very rich- $\mathrm{H}_{2}$ mixture, $\mathrm{C}$ coming from decomposition of $\mathrm{B}_{4} \mathrm{C}$ can react with $\mathrm{TiCl}_{4}$ to form $\mathrm{TiC}$.

\subsection{Experimental results and discussion}

\subsubsection{Coatings of a single layer of carbides}

The coating of $\mathrm{SiC}, \mathrm{TiC}$ and $\mathrm{B}_{4} \mathrm{C}$ on the carbon fibres was carried out using the reaction between the carbon of the fibre and a gaseous mixture of $\mathrm{H}_{2}$ and $\mathrm{SiCl}_{4}, \mathrm{TiCl}_{4}$ or $\mathrm{BCl}_{3}$, at normal pressure and at a temperature higher than $1000^{\circ} \mathrm{C}$. Table 1 gives a survey of the main temperatures and residence times for obtaining a coating thickness between 20 to $50 \mathrm{~nm}$ for each deposit. The layer thickness was determined from the weight of the bundle, the chemical analysis of the elements and the density of the carbide (3.21 g. $\mathrm{cm}^{-3}$ for $\mathrm{SiC}, 4.91 \mathrm{~g} . \mathrm{cm}^{-3}$ for $\mathrm{TiC}$ and $2.52 \mathrm{~g} . \mathrm{cm}^{-3}$ for $\mathrm{B}_{4} \mathrm{C}$ ) with the hypothesis that the thickness is the same on all the filaments of the bundle. Growth rate of a carbide layer is controlled by the diffusion of $\mathrm{C}$ atoms through this layer, thus the thickness increases linearly with square-root of the deposition time. However, as the treatment time was lower than 2 minutes, differences between the parabolic growth law and the experimental thickness was observed. This difference is certainly connected to microstructure and chemical reactivity of the fibres. Most of the graphite crystallites in the FT500 fibre have their basal planes aligned parallel to the fibre direction, thus few plane edges are exposed. Since the edges of the graphite planes are chemically much more reactive than the plane faces, higher-modulus fibres are less reactive than lower-modulus ones.

Table 1 : RCVD conditions for the formation of a single carbide coating on carbon fibres, $R$ being the ratio between the flows of $\mathrm{H}_{2}$ and halide

\begin{tabular}{llccc}
\hline Coatings & RCVD conditions & \multicolumn{3}{c}{ thickness (nm) } \\
& & T300 & M40B & FT500 \\
\hline SiC & $1200^{\circ} \mathrm{C}-1 \min -\mathrm{R}=2.3$ & 40 & 35 & 20 \\
$\mathrm{TiC}$ & $1000^{\circ} \mathrm{C}-0.8 \mathrm{~min}-\mathrm{R}=59.6$ & 30 & 30 & 20 \\
$\mathrm{~B}_{4} \mathrm{C}$ & $1300^{\circ} \mathrm{C}-1.5 \mathrm{~min}-\mathrm{R}=1.5$ & 40 & 40 & 30 \\
$\mathrm{~B}_{4} \mathrm{C}-\mathrm{SiC}$ & $1250^{\circ} \mathrm{C}-1.5 \mathrm{~min}-\mathrm{R}=10$ & 50 & & \\
\hline
\end{tabular}

SEM observation revealed that the surface morphology and the average diameter of the coated fibres are identical to those of raw fibres. The presence of the coating is evident after a complete gasification of the fibre carbon. The residue of a SiC coated fibre is shown in Figure 5. It consists in a thin and continuous shell that replicates the grooved morphology of the T300 fibre. This observation is the proof of a continuous initial carbide layer. 


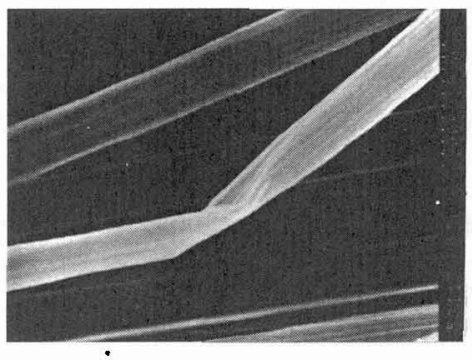

Figure 5: $\mathrm{SiC}_{-} \mathrm{SiO}_{2}$ continuous shell evidenced after combustion of carbon.

The effect of the different carbides on the tensile strength was investigated as a function of the thickness of the carbide layer. The results of the tensile tests for $\mathrm{T} 300 / \mathrm{SiC}, \mathrm{T} 300 / \mathrm{TiC}$ and $\mathrm{T} 300 / \mathrm{B}_{4} \mathrm{C}$ fibres are shown in table 2. All strength data are related to the total cross section, carbon filament plus coating.

Table 2: Tensile strength of carbide coated fibres (MPa)

\begin{tabular}{cccccc}
\hline thickness $(\mathrm{nm})$ & 10 & 20 & 50 & 70 & 100 \\
\hline T300/SiC & 3000 & 2900 & 2000 & 1700 & 1500 \\
T300/TiC & 2950 & 2500 & 1500 & 1200 & 1000 \\
T300/B $4 \mathrm{C}$ & 3050 & 3000 & 2500 & 1700 & 870 \\
\hline Weibull parameter & $5-5.5$ & $4-4.5$ & $3.6-4$ & $2.3-3.5$ & $1.5-1.9$ \\
\hline
\end{tabular}

It was suspected that the reduction of the strength is caused by the presence of a brittle coating on the surface of carbon fibres and by the consumption of the carbon to give carbide and hydrocarbon gas during the treatment. Moreover, temperature leads to an improvement in the degree of graphitization of the fibres. A second series of strength measurements were performed after the carbide coating had been removed with a mixture of $\mathrm{HNO}_{3}$ and HF. No practical difference in strength was observed between the carbide-removed fibres and the raw ones. This suggests that the observed change in the strength of the layered fibre is not caused by the attack of the carbon of the fibre during the RCVD process but it is caused by the existence of a brittle coating causing notches due to premature fracture.The fibres and the coating have different thermomechanical parameters as it is shown in table 3.

Table 3: Thermomechanical parameters

\begin{tabular}{lccccccc}
\hline Materials & $\begin{array}{c}\alpha \\
\left(10^{-6} \cdot{ }^{\circ} \mathrm{C}^{-1}\right)\end{array}$ & $\begin{array}{c}E_{\mathrm{R}} \\
\times 100\end{array}$ & $\begin{array}{c}\sigma_{\mathrm{R}} \\
(\mathrm{MPa})\end{array}$ & $\mathrm{K}_{1 \mathrm{C}}$ & $\begin{array}{c}\mathrm{E} \\
(\mathrm{GPa})\end{array}$ & $\begin{array}{c}v \\
\text { (Poisson) }\end{array}$ & Ref. \\
\hline SiC & 4.8 & 0.09 & 400 & 4.4 & 450 & 0.14 & {$[9]$} \\
$\mathrm{B}_{4} \mathrm{C}$ & 4.5 & 0.09 & 345 & $2.9-3.7$ & $360-460$ & $0.14-0.18$ & \\
TiC & 7.7 & 0.18 & $690-855$ & 5 & 410 & 0.19 & {$[9,10]$} \\
\hline T300 & $\alpha_{\mathrm{L}}=-0.5$ & 1.5 & 3180 & & $\mathrm{E}_{\mathrm{L}}=210$ & $v_{\mathrm{L}}=0.26$ & {$[11,12]$} \\
& $\alpha_{\mathrm{T}}=6.8$ & & & & $\mathrm{E}_{\mathrm{T}}=23$ & $v_{\mathrm{T}}=0.39$ & \\
\hline
\end{tabular}

Accordingly, when a tensile stress is applied to such a fibre, the coating layer first fractures and cracks are formed. When the thickness of the layer is above a certain value, the crack extends into the carbon fibre if the interfacial bonding between the coating and the carbon fibres is strong. In such a case, the strength of the coated fibre is proportional to the inverse of the square-root of the layer thickness [13-14]. The results of the tensile tests for $\mathrm{T} 300-\mathrm{SiC}, \mathrm{T} 300-\mathrm{TiC}$ and $\mathrm{T} 300-\mathrm{B}_{4} \mathrm{C}$ fibres are plotted against the inverse of the square-root of the layer thickness in Figure 6 and they confirm that all the coated fibres are fractured by such a mechanism. For the three systems $\mathrm{T} 300 / \mathrm{TiC}, \mathrm{T} 300 / \mathrm{B}_{4} \mathrm{C}$ and $\mathrm{T} 300 / \mathrm{SiC}$, the strength of the fibres begins to decrease when the thickness of the carbide layer is higher than $16 \mathrm{~nm}$. 

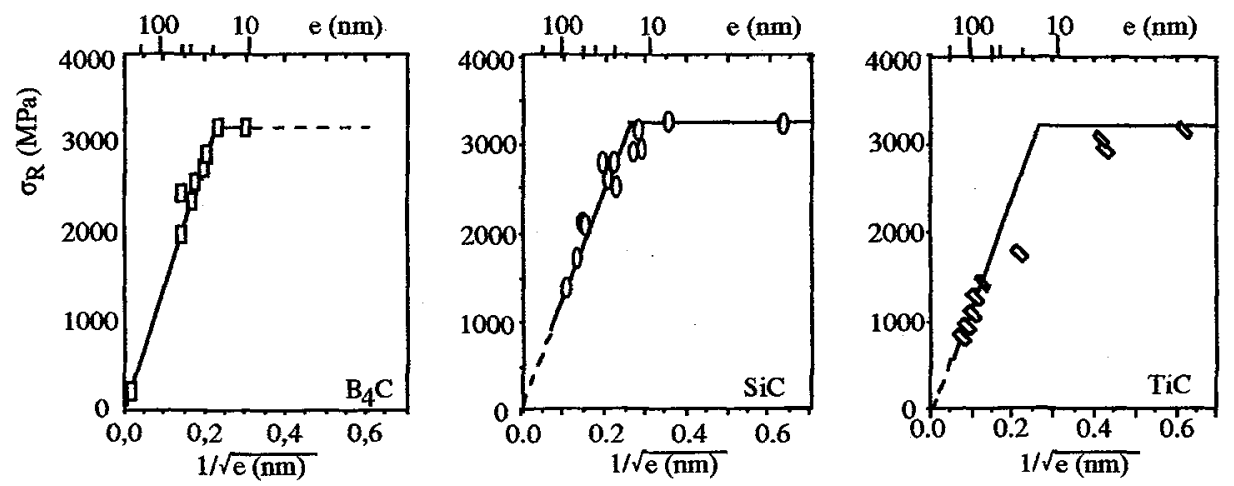

Figure 6: Variation of $\sigma_{R}$ as a function of (thickness $\left.-\mathrm{nm}\right)^{-1 / 2}$

\subsubsection{Double coatings}

2.3.2.1 Double coating: Pyrolytic carbon - carbide. The raw fibres were coated with a pyrolytic carbon film before the RCVD process. Propane was used as a source of carbon, and argon was used as a carrier gas. As the deposition rate of pyrolytic carbon must be controlled by the reaction of cracking and not by the diffusion rate of the gases to the fibre surface, the deposition was performed under $10 \mathrm{kPa}$. The concentration of propane was $20 \%$ while maintaining a total flow rate of $120 \mathrm{sccm}$. For providing the formation of bridges, the maximum $C$ coating thickness is limited up to $0.1 \mu \mathrm{m}$.

The results of the tensile tests for $C / C_{\text {pyro }}$ fibres are shown in table 4 . Substantial improvement in strength over that of the raw fibres was observed. Pyrocarbon has not only higher values of fracture elongation due to their laminar structure parallel to the surface, but also diminish the notches on the fibre surface itself.

Table 4: Tensile strength values of fibres coated by a carbon film

\begin{tabular}{lcc} 
& \multicolumn{2}{c}{$\sigma_{R}(\mathrm{MPa})$} \\
& without coating & with $\mathrm{C}_{\text {pyro coating }}$ \\
\hline T300-99 & 3150 & 4250 \\
M40B & 2740 & 3400 \\
FT500 & 3650 & 4300 \\
\hline
\end{tabular}

The $\sigma_{R}$ values of fibres coated a double layer of carbon and of a carbide are higher than ones measured on the fibres coated with the same carbide but without carbon underlayer (table 5). Most of them are higher than the one of the raw fibres. These results give proof that the carbon film acts effectively as an arrester of cracks formed in the upper layer of carbide.

Table 5: Tensile strength of fibres coated doubly by a carbon layer and a carbide layer

\begin{tabular}{|c|c|c|c|c|}
\hline & \multicolumn{4}{|c|}{$\sigma_{\mathrm{R}}(\mathrm{MPa})$} \\
\hline & without coating & $\mathrm{C}_{\text {pyro }}+\mathrm{SiC}$ & $\mathrm{C}_{\text {pyro }}+\mathrm{TiC}$ & $\mathrm{C}_{\text {pyro }}+\mathrm{B}_{4} \mathrm{C}$ \\
\hline T300-99 & 3150 & 3200 & 2700 & 3800 \\
\hline $\begin{array}{l}\text { M40B } \\
\text { FT500 }\end{array}$ & $\begin{array}{l}2740 \\
3560\end{array}$ & $\begin{array}{l}3200 \\
3900\end{array}$ & 3750 & 3480 \\
\hline
\end{tabular}

In this case, the interfacial bonding is weak, debonding occurs owing to shear stress at the interface during the deformation of the fibre under tension, and the crack edge is blunted in diminishing stress concentration. As a result, no loss in fibre strength takes place. Figure 7 confirms this hypothesis in the case of a TiC/C $\mathrm{C}_{\text {pyro }} /$ FT500 fibre: after a weak traction applied to a coated fibre, only the carbide layer is cracked. 


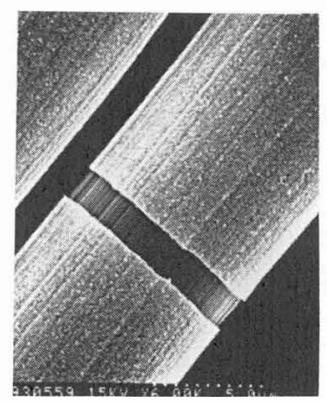

Figure 7: SEM image of FT500 fibre covered by a double layer $\mathrm{C}_{\text {pyro }}-\mathrm{TiC}$

2.3.2.2 Double coating: carbide - carbide or carbide - boride. The raw fibres were coated with a first film of carbide, then a second RCVD process was performed to transform a part of the carbide into a new layer. Double coatings $\mathrm{SiC} / \mathrm{B}_{4} \mathrm{C}$ and $\mathrm{B}_{4} \mathrm{C} / \mathrm{TiB}_{2}$ were obtained by this way. After optimization of the coating conditions, the mechanical properties of the as-coated fibres are near the ones of the fibres with a single coating (table 6).

Table 6: Effect of a carbide coating on the failure strength of T300 fibres

\begin{tabular}{|c|c|c|c|}
\hline Coated fibres & $\sigma_{\mathrm{R}}(\mathrm{MPa})$ & $\Delta \sigma_{\mathrm{R}} / \sigma_{\mathrm{R}}(\%)$ & Thickness (nm) \\
\hline $\mathrm{T} 300(\mathrm{SiC})$ & 2630 & -15 & SiC $: 20$ \\
\hline $\mathrm{T} 300\left(\mathrm{~B}_{4} \mathrm{C}\right)$ & 2870 & -19 & $\mathrm{~B}_{4} \mathrm{C}: 30$ \\
\hline $\mathrm{T} 300\left(\mathrm{~B}_{4} \mathrm{C} / \mathrm{SiC}\right)$ & 2750 & -19 & $\overline{\mathrm{B}_{4} \mathrm{C}: 20}$ \\
\hline $\mathrm{T} 300\left(\mathrm{~B}_{4} \mathrm{C} / \mathrm{TiB}_{2}\right)$ & 2200 & -30 & $\mathrm{TiB}_{2}:<10$ \\
\hline
\end{tabular}

\subsubsection{Protecting effect of the coatings}

The efficiency of $\mathrm{SiC}, \mathrm{B}_{4} \mathrm{C}$ and $\mathrm{SiC}-\mathrm{B}_{4} \mathrm{C}$ mixed layer was demonstrated in the case of $\mathrm{Al} / \mathrm{C}$ composites manufactured by squeeze-casting technique (table 7 ).

Table 7: Tensile strengths of coated T300 fibres and Al-C composites

\begin{tabular}{l|c|c}
\hline & \multicolumn{2}{|c}{$\sigma_{\mathrm{R}}(\mathrm{MPa})$} \\
\cline { 2 - 3 } & fibres & Al-C composites \\
\hline T300 & 3150 & 370 \\
$\mathrm{~T} 300 / \mathrm{TiC}$ & 2500 & 425 \\
$\mathrm{~T} 300 / \mathrm{SiC}$ & 2700 & 1050 \\
$\mathrm{~T} 300 / \mathrm{B}_{4} \mathrm{C}$ & 2870 & 990 \\
T300/B4C-SiC & 2970 & - \\
T300/B4C-SiC extracted from Al matrix & 3100 & - \\
\hline
\end{tabular}

The $\mathrm{SiC}, \mathrm{B}_{4} \mathrm{C}$ and $\mathrm{B}_{4} \mathrm{C}-\mathrm{SiC}$ coatings prevent reaction between the fibre carbon and aluminium. Pull-out was observed on rupture facies of composites (Figure 8a) and no reaction product was evidenced at the interface by TEM as it is shown in Figure $8 b$ [15]. 


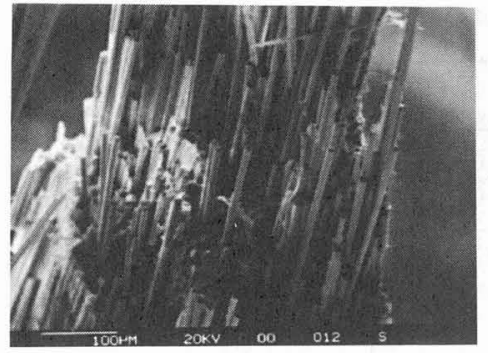

Figure 8a: SEM observation of the rupture facies of a Al-T300/SiC composite.

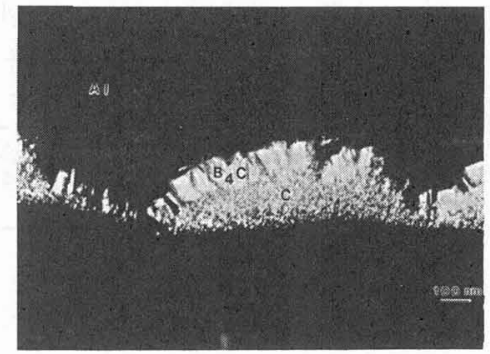

Figure 8b: TEM observation of the interface in a Al$\mathrm{T} 300 / \mathrm{B}_{4} \mathrm{C}$ composite.

This absence of reactivity was confirmed by tensile tests on monofilaments performed after metal dissolution (see table 7).

The following results confirm that the single or duplex layers of carbide coatings are able to slow down the gasification of carbone fibres in oxygen. For this study, oxidation experiments in dry flowing oxygen were carried out at $600^{\circ} \mathrm{C}$ via thermogravimetric analysis. The coated T300 fibre behaviour is summarized in Figure 9.

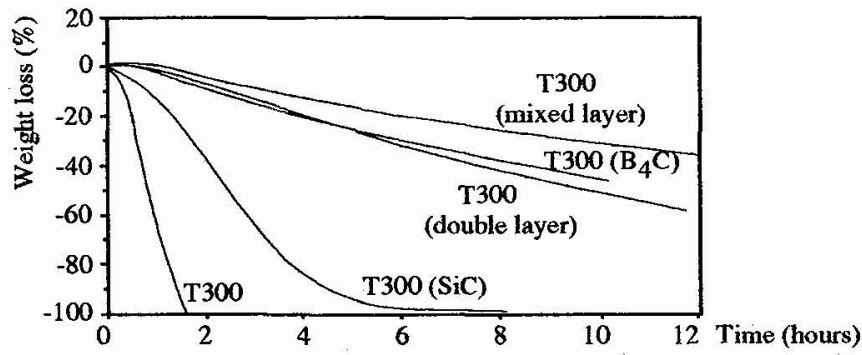

Figure 9: Thermogravimetric curves of coated $\mathrm{T} 300\left(600^{\circ} \mathrm{C}, \mathrm{pO}_{2}=1 \mathrm{~atm}\right)$

The thermogravimetric curves confirm that all the $\mathrm{B}_{4} \mathrm{C}$-based coatings have a better protecting behaviour than the SiC based ones, whatever the oxidation time. Borosilicate and boron oxide glasses are formed during the exposure and provide a similar inhibition behaviour during the first two hours of exposure to oxygen. For a longer duration, the mixed layer seems to be the best protective coating because borosilicate coating is more stable than boron oxide [16].

Concurrently, we have measured the mechanical properties of the fibres as a function of the oxidation time (Table 8). The $\sigma_{R}$ values of the raw T300 fibre drop strongly. Above ten minutes, the filaments are very brittle and they can not be tested. $\mathrm{B}_{4} \mathrm{C}$-based coated fibres lead to better results than $\mathrm{SiC}$-coated fibres. The double layer and the mixed layer coated fibres are found to retain the $\sigma_{R}$ values during an oxidation run time of 30 minutes : the decrease is only $0-7 \%$ compared to the initial $\sigma_{R}$ value, whereas the single $\mathrm{B}_{4} \mathrm{C}$ or $\mathrm{SiC}$ coated fibres present respectively $15 \%$ and $30 \%$ strength losses. Table 8 evidences that the tensile strength lowering and the measured weight losses have not a direct relation. 
Table 8: Evolution of fibre tensile strength and weight loss as a function of oxidizing time, at $600^{\circ} \mathrm{C}$.

\begin{tabular}{lrrr}
\hline Fibres & $\begin{array}{c}\text { Time } \\
(\mathrm{min})\end{array}$ & $\begin{array}{r}\text { Weight loss } \\
(\%)\end{array}$ & $\begin{array}{r}\Delta \sigma / \sigma_{\mathrm{R}} \\
(\%)\end{array}$ \\
\hline T300 & 0 & 0 & 0 \\
& 10 & -10 & -40 \\
& 15 & -20 & - \\
\hline T300 (SiC) & 0 & 0 & 0 \\
& 10 & -0.6 & -15 \\
& 20 & -1.2 & -30 \\
T300 (B 4 C) & 60 & -5.1 & -40 \\
\hline T300 & 0 & 0 & 0 \\
(SiC/B 4 C double layer) & 30 & 1 & -15 \\
& 60 & 1 & -30 \\
\hline T300 & 0 & 0 & 0 \\
(SiC-B 4 C mixed layer) & 60 & -0.2 & 0 \\
& 0 & -2.1 & 0 \\
\hline
\end{tabular}

\section{OPTIMIZATION OF THE METAL MATRIX COMPOSITION}

In addition to surface treatments, a better control of the reactivity and bonding in carbon fibre reinforced metal matrix composites may be achieved by optimizing the composition of the matrix. For reactive systems such as Al-C composites, the composition of the matrix will be modified in order to reduce its chemical reactivity with the outer fibre coatings. For non-reactive systems such as $\mathrm{Mg}$-C composites, the objective will be to induce a controlled interfacial reaction promoting wetting and bonding. Such approaches will be illustrated by the three forthcoming examples.

\subsection{Reactivity control at the Al/SiC interface}

In the continuation of previous works by Bermudez [17] and by Iseki et al. [18], a model based on stable and metastable phase equibria has been developed for describing the chemical interaction under atmospheric pressure between $\mathrm{Al}$ and $\mathrm{SiC}$ at low and medium temperatures [19]. According to this model, an invariant transformation (quasi-peritectic reaction) occurs in the Al-C-Si system at $650 \pm 3^{\circ} \mathrm{C}$. This transformation which can be written :

$$
\mathrm{SiC}+\mathrm{Al} \Leftrightarrow \mathrm{Al}_{4} \mathrm{C}_{3}+\mathrm{L}_{0}
$$

corresponds to a non-reactive/reactive transition for the $\mathrm{Al}-\mathrm{SiC}$ couple $\left(\mathrm{L}_{0}\right.$ designates a binary $\mathrm{Al}-\mathrm{Si}$ liquid containing $1.5 \pm 0.4$ at.\% $\mathrm{Si}$ ). In other words, $\mathrm{SiC}$ is in thermodynamic equilibrium with solid aluminium at temperature lower than $650^{\circ} \mathrm{C}$ and reacts with solid $\left(650<\mathrm{T}<660^{\circ} \mathrm{C}\right)$ or liquid $\left(\mathrm{T}>660^{\circ} \mathrm{C}\right)$ aluminium at any temperature higher than $650^{\circ} \mathrm{C}$, producing $\mathrm{Al}_{4} \mathrm{C}_{3}$ and silicon. The phase field arrangements typical for these two different temperature ranges are represented in Figure 10.

According to this model, no reaction will occur at the $\mathrm{Al} / \mathrm{SiC}$ interface as long as the temperature will remain lower than $650^{\circ} \mathrm{C}$ (in this low temperature range, the mutual solubilities between $\mathrm{Al}$ and $\mathrm{SiC}$ are negligible). This is illustrated by the micrograph presented in Figure 11 that has been taken on a $\alpha$-SiC quasi-single crystalline particle annealed for a very long time $\left(1200\right.$ hours) at $570^{\circ} \mathrm{C}$ in the presence of pure Al. On the other hand, decomposition of $\mathrm{SiC}$ into $\mathrm{Al}_{4} \mathrm{C}_{3}$ and $\mathrm{Si}$ will generally be observed at temperatures higher than $650^{\circ} \mathrm{C}$, the reaction rate increasing with the temperature. Figure 12 illustrates the rapid formation, via a dissolution-precipitation mechanism, of $\mathrm{Al}_{4} \mathrm{C}_{3}$ crystals at the surface of $\alpha$-SiC particles after 1 hour heating at $1000^{\circ} \mathrm{C}$ [20]. It can however be remarked that a three-phased monovariant equilibrium between $\mathrm{SiC}, \mathrm{Al}_{4} \mathrm{C}_{3}$ and an $\mathrm{Al}-\mathrm{Si}$ liquid phase exists in the ternary $\mathrm{Al}-\mathrm{C}$-Si phase diagram at temperatures higher than $650^{\circ} \mathrm{C}$. The silicon content of the $\mathrm{Al}-\mathrm{Si}$ liquid phase involved in this monovariant equilibrium has been determined at different temperatures: it increases regularly from 1.5 at. $\%$ at $650^{\circ} \mathrm{C}$ to

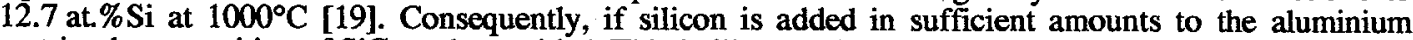
matrix, decomposition of $\mathrm{SiC}$ can be avoided. This is illustrated by the micrograph presented in Figure 13 
where it can be seen that no reaction has occured at the surface of $\alpha$-SiC particules heat-treated for 1 hour at $1000^{\circ} \mathrm{C}$ (same conditions as in Figure 12) in an Al-Si alloy containing 13 at.\% Si. Practically, to avoid the formation of $\mathrm{Al}_{4} \mathrm{C}_{3}$ at the $\mathrm{Al}-\mathrm{SiC}$ interface at $730^{\circ} \mathrm{C}$ (the highest temperature at which liquid phase infiltration of fibre reforms is generally performed) the silicon content in the aluminium matrix should be higher than or equal to 5 at.\% [19].
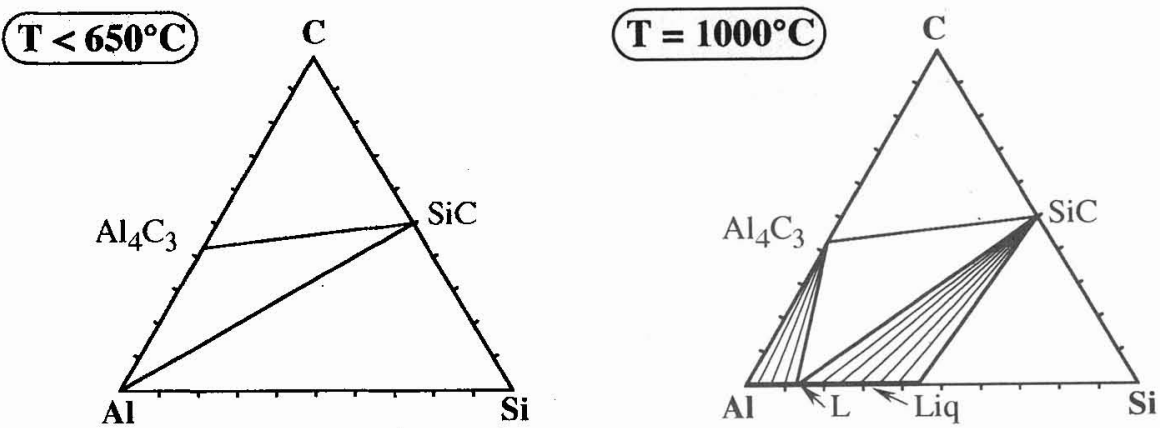

Figure 10: Typical isothermal sections of the Al-C-Si phase diagram below and above the invariant transformation at $650^{\circ} \mathrm{C}$

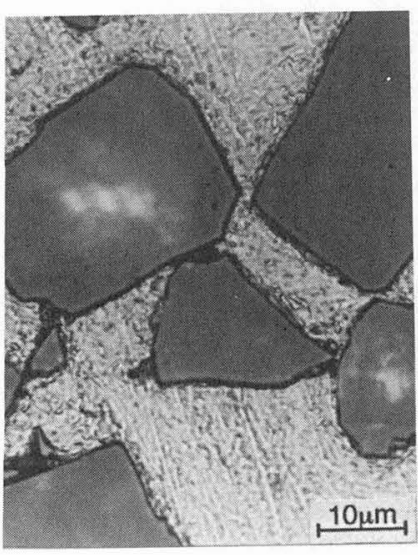

Figure 11: The $\mathrm{Al} / \alpha-\mathrm{SiC}$ interface after annealing for 1200 hours at $570^{\circ} \mathrm{C}$ : no interface reaction.

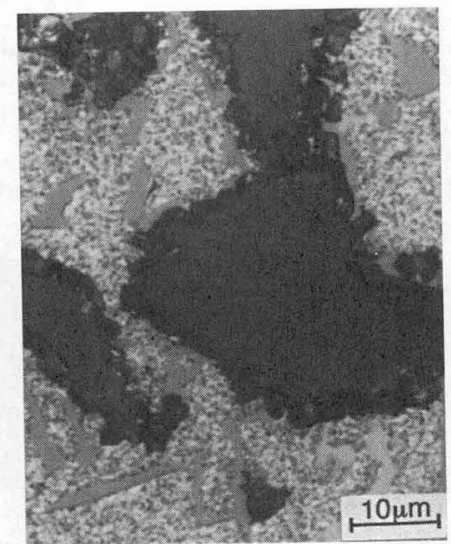

Figure 12: Strong reaction at the $\mathrm{Al} / \alpha-\mathrm{SiC}$ interface after heating for 1 hour at $1000^{\circ} \mathrm{C}$.

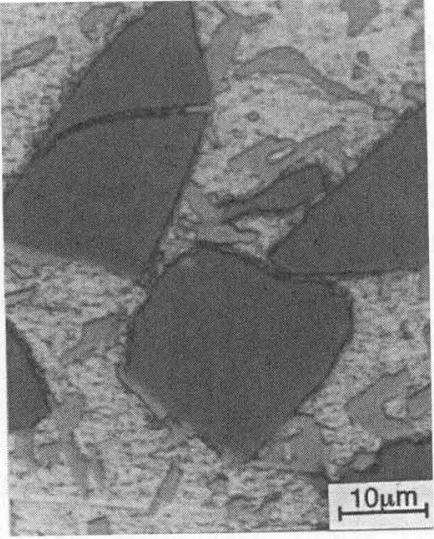

Figure 13: $\mathrm{Al} / \alpha-\mathrm{SiC}$ interface after 1 hour heating at $1000^{\circ} \mathrm{C}$.

In this first example, the control of the chemical interaction at the matrix/reinforcement interface is based on thermodynamics: the operating parameters are adjusted (temperature lower than $650^{\circ} \mathrm{C}$ or addition of a sufficient amount of silicon to aluminium) in such a way that equilibrium conditions are realized. We will now describe another example, the AlTiC couple, where the control of the interfacial reaction may be based either on thermodynamics or on kinetics.

\subsection{The case of the Al/TiC interface}

From a thermodynamic point of view, the chemical behaviour of the Al/TiC interface is opposite to that of the $\mathrm{Al} / \mathrm{SiC}$ interface in the sense that this interface is reactive at low temperature and non-reactive at medium 
or high temperature. The reactive/non-reactive transition corresponds to the invariant transformation (quasiperitectic reaction) :

$$
\mathrm{L}+\mathrm{TiC}_{\mathrm{X}} \Leftrightarrow \mathrm{Al}_{4} \mathrm{C}_{3}+\mathrm{Al}_{3} \mathrm{Ti}
$$

where $\mathrm{L}$ designates an $\mathrm{Al}$ base liquid phase containing about 0.3 at.\% $\mathrm{Ti}$ and $\mathrm{TiC}_{\mathrm{x}}$ a carbon-rich titanium carbide phase with $\mathrm{x}>0.9$. This transformation has been found to occur at $812 \pm 15^{\circ} \mathrm{C}$ [21]. Consequently, as shown by Figure 14, aluminium and titanium carbide react at temperatures lower than $812^{\circ} \mathrm{C}$ to give the two solid phases $\mathrm{Al}_{4} \mathrm{C}_{3}$ and $\mathrm{Al}_{3} \mathrm{Ti}$ and are in equilibrium at temperatures higher than $812^{\circ} \mathrm{C}$. Exploitation of these thermodynamic principles provides a first mean to avoid the chemical interaction at the $\mathrm{Al} / \mathrm{TiC}$ interface. It suffices to increase the processing temperature up to a level higher than $812^{\circ} \mathrm{C}$ and to cool rapidly the material at the end of the process. It can be remarked that in the absence of precise thermodynamic data, such a solution would not have appeared as obvious.
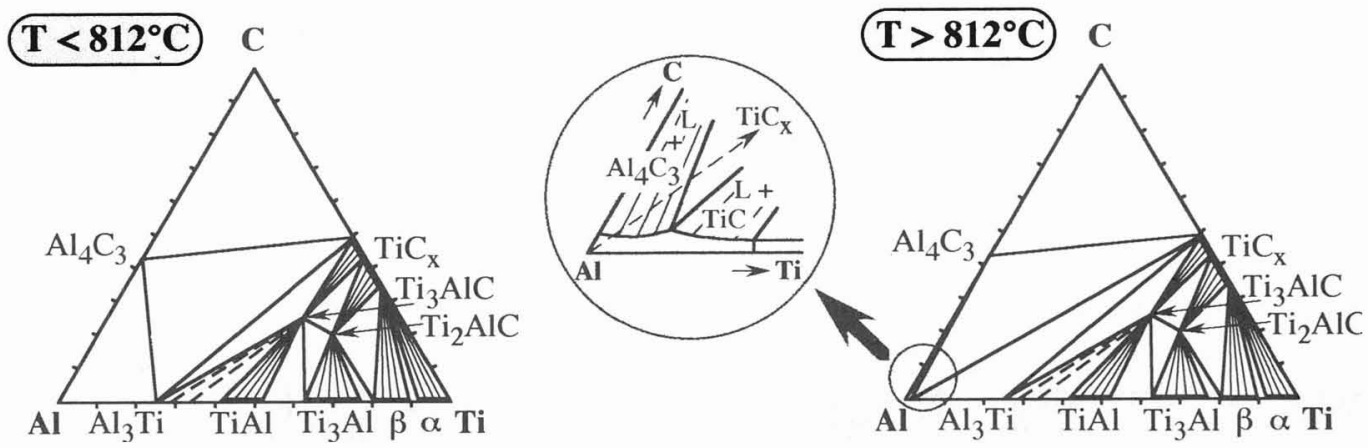

Figure 14: Isothermal sections of theAl-C-Ti phase diagram below and under the invariant transformation at $812^{\circ} \mathrm{C}$.

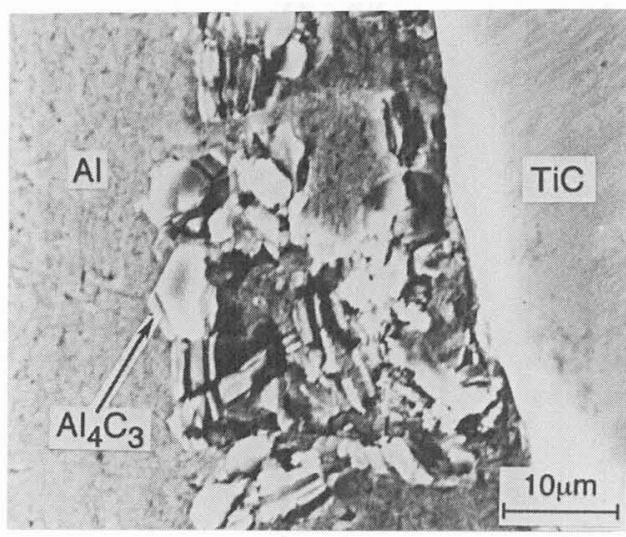

Figure 15: $\mathrm{TiC}_{\mathrm{x}}$ single crystal after annealing for 150 hours at $730^{\circ} \mathrm{C}$ in a large excess of pure aluminium.

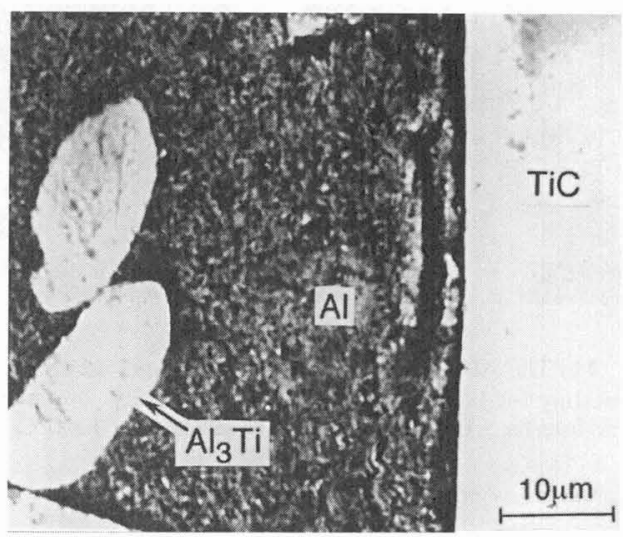

Figure 16: $\mathrm{TiC}_{\mathrm{x}}$ single crystal after annealing for 150 hours at $730^{\circ} \mathrm{C}$ in a 1. at. \% Ti Al-Ti alloy.

Another means to control the interfacial reaction between aluminium and titanium carbide has arisen from further investigations of the kinetic aspect of the chemical interaction at the A1/TiC interface. In these investigations, we have found that decomposition of titanium carbide by reaction with liquid aluminium below $812^{\circ} \mathrm{C}$ proceeded in two successive stages:

- in a first stage, $\mathrm{Al}_{4} \mathrm{C}_{3}$ crystals nucleate and grow whereas titanium simply dissolves in liquid aluminium. This first stage reaction which progresses at a rather fast rate is depicted by the SEM 
micrograph reported in Figure $15 . \mathrm{Al}_{4} \mathrm{C}_{3}$ crystals grown by dissolution-precipitation can be observed near the surface of a carbon-rich titanium carbide single crystal that has been immersed for 150 hours at $730^{\circ} \mathrm{C}$ in a large excess of pure aluminium. It can be noted that the single crystal surface has become rough while the aluminium matrix still exhibits a single-phased appearence;

- when the titanium content in the aluminium base liquid has attained its saturation value (about 0.2 at. $\% \mathrm{Ti}$ at $730^{\circ} \mathrm{C}$ ), one enters in a second stage reaction where $\mathrm{Al}_{4} \mathrm{C}_{3}$ continues to grow as previously but where $\mathrm{Al}_{3} \mathrm{Ti}$ crystals also nucleate and develop in the liquid phase. This second stage reaction proceeds, however, at a much slower rate than the first one. As illustrated by the SEM micrograph reported in Figure 16, no trace of $\mathrm{Al}_{4} \mathrm{C}_{3}$ is visible at the interface between a $\mathrm{TiC}_{\mathrm{x}}$ single crystal and a Ti-saturated aluminium matrix after 150 hours immersion at $730^{\circ} \mathrm{C}$. In that case, the surface of the $\mathrm{TiC}_{\mathrm{x}}$ single crystal is smooth. Al3Ti globular crystals are present in the matrix but they do not result from the decomposition of $\mathrm{TiC}_{\mathrm{x}}$; they were formed at the beginning of the heat-treatment by precipitation from the Ti-sursaturated aluminium base alloy (initial Ti content 1 at.\%).

Decomposition of $\mathrm{TiC}_{\mathrm{x}}$ by liquid $\mathrm{Al}$ below $812^{\circ} \mathrm{C}$ can thus be controlled, to a certain extent, by exploiting these chemical kinetics data. Accordingly, if the aluminium matrix is just saturated in titanium prior to liquid phase processing below $812^{\circ} \mathrm{C}$, only the second stage reaction will be possible at the metal/carbide interface and this second stage reaction will progress only at a very slow rate.

\subsection{Reactivity control at the $\mathrm{Mg} / \mathrm{C}$ interface}

In the two preceeding examples, the considered systems were reactive and the objective was to avoid the degradation of the fibre coatings, $\mathrm{SiC}$ or $\mathrm{TiC}$, by chemical reaction with the matrix and the subsequent formation of a too strong interfacial bonding. In this third example concerning the $\mathrm{Mg} / \mathrm{C}$ couple, the system is essentially non-reactive [22] and liquid magnesium does not wet carbon, as illustrated by Figure 1b. In that case, the objective will then consist in promoting a controlled reaction in order to improve wetting and bonding at the metal/fibre interface.

It has been found that this could be achieved by adding little amounts of zirconium to the magnesium matrix [23]. Effectively, when a carbon fibre tow (3000-6000 filaments) is immersed at $650-750^{\circ} \mathrm{C}$ under an atmospheric pressure of argon in a liquid magnesium base alloy saturated in zirconium, i.e. containing 0.15-0.2 at.\% $\mathrm{Zr}$, the liquid metal penetrates within the filaments of the tow and the latter can be completely infiltrated by the matrix, as shown by Figure 17a. One of the main factors that determines this very interesting wetting behaviour is the fact that a layer of zirconium carbide $\mathrm{Zr}_{\mathbf{X}} \mathrm{C}_{\mathrm{X}}$ is rapidly formed at the surface of the carbon filaments by chemical reaction with the liquid alloy. Figure $17 \mathrm{~b}$ illustrates three characteristic features of this layer: microcrystalline character, continuity and uniform thickness. It also shows that after 1 hour immersion at $680^{\circ} \mathrm{C}$, the $\mathrm{ZrC}$ layer surrounding $\mathrm{M} 40 \mathrm{~B}$ type carbon fibres (exPAN, $6 \mu \mathrm{m}$ in diameter) has a mean thickness of $0.5 \mu \mathrm{m}$. For a shorter immersion time, 15 minutes, the $\mathrm{ZrC}_{\mathrm{X}}$ layer is thinner, about $0.25 \mu \mathrm{m}$, but already continuous (Figure 18).

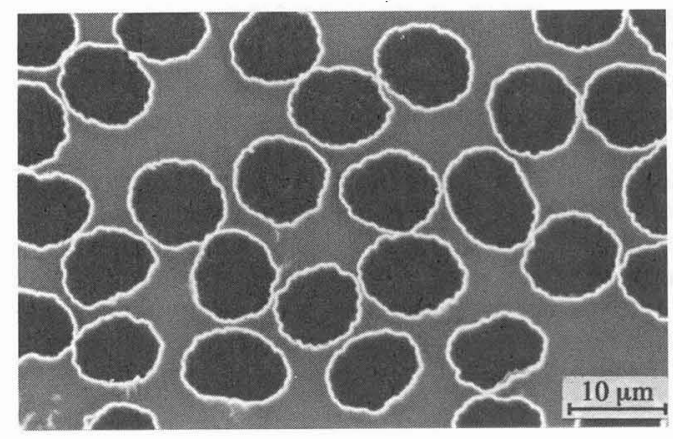

a)

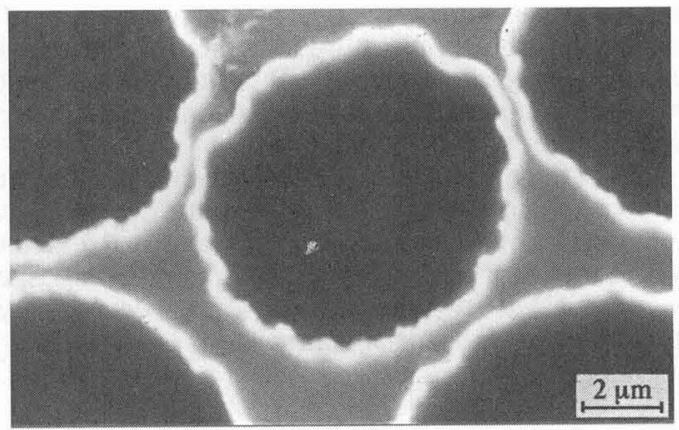

b)

Figure 17: M40B carbon filaments embedded in a $\mathrm{Zr}$-saturated $\mathrm{Mg}-\mathrm{Zr}$ matrix $(0.15-0.2$ at.\% $\mathrm{Zr}$ ) after immersion for 1 hour at $680^{\circ} \mathrm{C}$; (a): general view; (b) detailed view showing the $\mathrm{ZrC}_{\mathrm{X}}$ interfacial layer about $0.5 \mu \mathrm{m}$ thick. 
In fact, a study of the mechanism of the chemical reaction between carbon fibres and liquid $\mathrm{Mg}-\mathrm{Zr}$ alloys has revealed that the growth of the $\mathrm{ZrC}_{\mathrm{X}}$ layer proceeds via a unidirectionnal solid state diffusion of carbon from the fibre surface to the $\mathrm{Mg}-\mathrm{Zr}$ matrix. As a consequence of this unidirectional diffusion of carbon, Kirkendall voids form at the outer part of the carbon fibres, just below the $\mathrm{ZrC}_{\mathrm{X}} / \mathrm{C}$ interface. $\mathrm{A}$ weakened zone is then created between the fibre and the $\mathrm{ZrC}_{\mathrm{x}}$ layer and it is in this weakened zone that cracks will propagate when a stress is applied to the material. Such a situation is depicted in Figure 19. It can then be easily understood that, by varying the infiltration time and temperature, one can adjust to a certain extent the strength of the bonding between the carbon fibres and the $\mathrm{Mg}-\mathrm{Zr}$ matrix.

Such an interface tailoring is rendered possible by the particular mechanism of growth of the $\mathrm{ZrC}_{\mathrm{x}}$ reaction layer at the metal/fibre interface. Effectively, if the growth of the reaction layer does not proceed by solid state diffusion of carbon but by liquid phase dissolution-recrystallisation, which is the case if aluminium replaces zirconium in the magnesium matrix, a carbide reaction layer, $\mathrm{Al}_{2} \mathrm{MgC}_{2}$ [24] also forms but this layer is very irregular and the fibre is severely attacked. In that case, the interface exhibits exactly the same morphology as that presented in figure 1a.

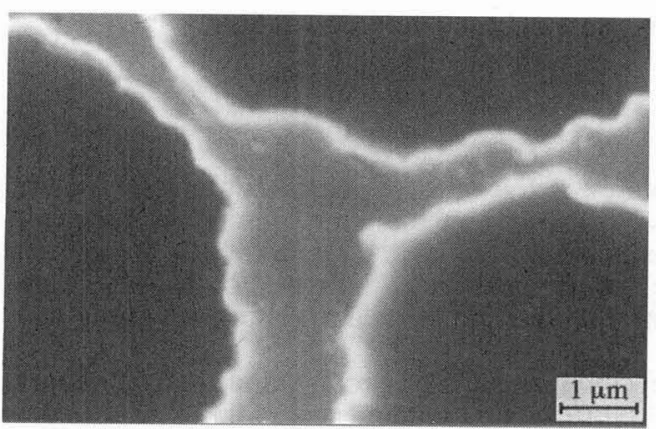

Figure 18: Detailed view of the interface between M40B carbon filaments and a $\mathrm{Mg}-\mathrm{Zr}$ alloy $(0.15-0.2$ at. $\% \mathrm{Zr})$ after immersion for 15 minutes at $680^{\circ} \mathrm{C}$ : the $\mathrm{ZrC}_{\mathrm{X}}$ layer thickness is about $0.25 \mu \mathrm{m}$.

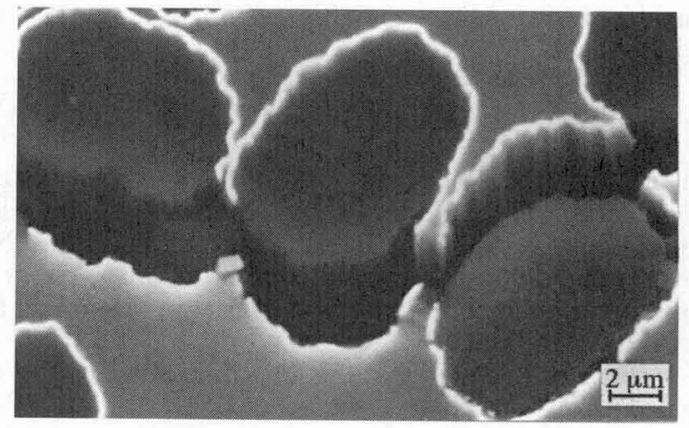

Figure 19: Crack propagation along the $\mathrm{C} / \mathrm{ZrC} \mathrm{C}_{\mathrm{X}}$ interface (weakened by Kirkendall voids) in a $\mathrm{M} 40 \mathrm{~B} / \mathrm{Mg}-\mathrm{Zr}$ microcomposite.

\section{CONCLUSION}

As already emphasized, avoiding the degradation of the reinforcement by chemical interaction with the matrix and controlling the nature and strength of the interfacial bonding are two keys to the development of high performance metal matrix composite materials. As shown by the different results reported in the present paper, this can be achieved in $\mathrm{C}-\mathrm{Al}$ or $\mathrm{C}-\mathrm{Mg}$ composites both by surface treatment of the reinforcing fibres and by optimization of the metal matrix composition. In this regard, an Al-Si matrix should be more appropriate than a pure $\mathrm{Al}$ matrix for infiltrating SiC-coated carbon fibres near $700^{\circ} \mathrm{C}$. In the same connection, using a Ti-saturated $\mathrm{Al}$ matrix should be better than using pure $\mathrm{Al}$ for infiltrating carbon fibres with a TiC coating.

Whatever the solution developed, it is clear that successful tailoring of the interface properties of composite systems will always require a thorough understanding of the chemistry of these systems, in terms of thermodynamics, kinetics and reaction mechanisms. It is with this care in mind that we are conducting further studies on metal matrix composites. In the case of carbon fiber reinforcements, this task is complicated by the existence of a wide variety of fibers that may exhibit very different chemical reactivities towards metal matrices.

\section{References}

[1] Chawla K.K. in "Materials Science and Technology", Cahn R.W., Haasen P. and Kramer E.J. Eds., Vol. 13 (VCH, Weinheim, 1993) p. 121-182.

[2] Maruyama B., Barera E.V. and Rabenberg L., in "Metal Matrix Composites Processing and Interfaces", (Everett R.K. and Arsenault R.J. Eds., Academic Press, 1991) p.181-216. 
[3] Bouix J., Cromer M., Dazord J., Mourichoux M., Ponthenier J.L., Scharff J.P., Vincent C., Vincent H., Bernard C., Rev. Int. Hautes Temp. Réfract. Fr. 24 (1987) 5-26

[4] Vincent C., Dazord J., Vincent H., Bouix J., Thermochim. Acta 138 (1989) 81-96

[5] Vincent H., Mourichoux H., Scharff J.P., Vincent C., Bouix J., Thermochim. Acta 182 (1991) 253272

[6] Piquero T., Bouix J., Scharff J.P., Vincent C., Vincent H., J. Alloys and Compounds 185 (1992) 121-144

[7] Vincent C., Piquero T., Berthet M.P., Vincent H., Bouix J., Mater. High Temp. 13 (1) (1995) 17-28

[8] Piquero T., Vincent H., Vincent C., Bouix J., J. Mater. Synt. Process. 3(4) (1995) 231-245

[9] Shaffer P.T.B., Engineered Materials : Handbook of Ceramics and Glasses, ASM International, vol.4, pp. 804-811

[10] Toth L.E., "Transition metal carbides and nitrides", Academic Press, 1971

[11] Villeneuve J.F., Naslain R., Severy J., Fourmeaux R., ECCM5, Bordeaux 7-10 April 1992, A.R. Bunsell, Jamet, A., Massiah ed., pp.753-758

[12] Menessier E., Dumont J.P., Guette A., Pailler R., Rabardel L., Naslain R., Ceram. Engineering Science Proceedings 10 (1989) 1426-1334

[13] Ochiai S., Murakami Y., J. Mater. Sci. 14 (1979) 831-840

[14] Ochiai S., Murakami Y., Metall. Trans. 12 A (1981) 1155-1161

[15] Vincent H., Vincent C., Berthet M.P., Bouix J., Gonzales G., Carbon 34(9) (1996) 1041-1055

[16] Piquero T., Vincent H., Vincent C., Bouix J., Carbon 33(4) (1995) 455-467

[17] Bermudez V.M., Appl.' Phys. Lett. 42 (1983) 70-73.

[18] Iseki T., Kameda T. and T. Maruyama, J. Mater. Sci. 19 (1984) 1692-1698.

[19] Viala J.C., Fortier P. and Bouix J., J. Mater. Sci. 25 (1990) 1842-1850.

[20] Viala J.C., Bosselet F., Laurent V., Lepetitcorps Y., J. Mater. Sci. 28 (1993) 5301-5312.

[21] Viala J.C., Vincent C., Vincent H. and Bouix J., Mat. Res. Bull. 25 (1990) 457-464.

[22] Viala J.C., Fortier P., Claveyrolas G., Vincent H., Bouix J., J. Mater. Sci. 26 (1991) 4977-4984.

[23] Abiven H., Bouix J., Claveyrolas G., Picouet L., Viala J.C., Composite material combining a magnesium alloy containing zirconium with a carbon reinforcement and its production process, US Patent Demand US 08/417 444 accorded 2 Feb. 1996.

[24] Viala J.C., Bosselet F., Claveyrolas G., Mentzen B.F. and Bouix J., Eur. J. Solid State Inorg. Chem. 28 (1991) 1063-1070. 